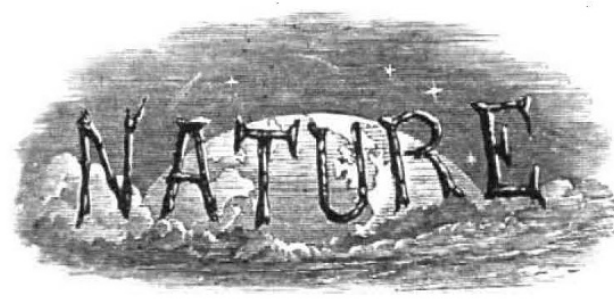

SATURDAY, SEPTEMBER I5, 1928.
The International Research Council.

T THE International Research Council, of which 1 the fourth general assembly was held at Brussels in July, was formed in 1919, and the convention under which it carries on its work will terminate at the end of 1931 unless it has been previously renewed by the countries represented on the Council.

Designed to replace some of the international scientific associations that had lapsed during the War, its aims have been defined to be to co-ordinate international efforts in the different branches of science; to initjate the formation of international scientific associations; to direct international scientific activity in subjects not falling within the purview of any existing association; and to enter into relation with the governments of the countries adhering to the Council in order to promote investigations falling within its competence.

The countries which joined the Council at its formation were fifteen in number, but since then many others have notified their adhesion to it, until at the present time thirty-five countries are represented on the Council and take part in its deliberations.

One of the first acts of the Council was to promote the formation of international associations, or Unions, for the furtherance of certain branches of science in which international co-operation is essential, with the result that the Unions of Astronomy, of Geodesy and Geophysics, of Pure and Applied Chemistry, of Mathematics, and of RadioTelegraphy were formed in 1919. Later, in 1922, others dealing with Pure and Applied Physics, Biological Sciences, and Geography were organised, thus bringing the total number up to eight.

These Unions are practically autonomous, arranging their own meetings, appointing their own officers, collecting and dispensing their own funds, and initiating research and co-operative work in their own fields of scientific activity, very much as did the earlier associations the work of which they are carrying on.

During the past nine years, each of these Unions has held several meetings at which addresses have been delivered, scientific communications have been discussed, and arrangements have been made for future co-operation and research. The Astronomical Union, which has now been joined by 24 countries, has met at Rome, Cambridge, and Leyden; the Geodetic and Geophysical Union, which has a membership of 32 countries, has held meetings at Rome, Madrid, and Prague; the Chemical Union, representing 28 countries, has

Telegraphic Address: PHUSIS, WESTRAND, LONDON. No. 3072, VoL. 122] 
hitherto met annually, and has visited Rome, Brussels, Lyons, Cambridge, Copenhagen, Bucarest, Warsaw, and the Hague. The Mathematical Union, to which 18 countries belong, has held meetings at Strasbourg and Toronto, and has just met at Bologna. The Union of RadioTelegraphy, with a membership of 11 countries, has met at Brussels and at Washington. Of those which were formed later, the Physical Union has met at Paris and Brussels; the Geographical Union has met at Brussels, Cairo, and Cambridge; and the Biological Union at Brussels, Paris, and Geneva. The membership of these three Unions is now 18, 19 , and 14 countries respectively.

Thus it will be seen that all these associations are now well supported, and are operating actively and effectively in the promotion of science and in the encouragement of international co-operation. In none of their work does the Research Council intervene. A reference to the published accounts of its meetings will show that most of the questions with which it has dealt are of an administrative rather than of a scientific character. They include invitations to join the organisation, the appointment of its officers and of committees, approval of statutes or of modifications to statutes which have been proposed by any of the Unions, and other matters affecting the Council and the Unions related to it as a whole. On occasions it has appointed committees to carry out special inquiries, such as the one which is studying the relations between solar and terrestrial phenomena, but generally the delegates, of whom it is composed and who are almost without exception delegates also to one Union or another, are called upon to decide questions of administration and not scientific matters. The conception of the Council as a small body which aims at exercising a control in scientific matters falls very wide of the mark, since it is one on which all the thirty-five countries are represented.

In 1926 the delegates of the countries adhering to the Council unanimously decided to invite Germany, Austria, Hungary, and Bulgaria to join the Council and the Unions related to it, and to give effect to this, invitations were sent out immediately after the meeting. At the meeting of the general assembly in July, it was reported that Hungary had accepted the invitation and had joined the Council, but that Bulgaria, for reasons of economy, was unable to do so at present. Germany and Austria had not yet replied. In Germany the matter is believed to be still under consideration by the five scientific academies of that country, namely, those of Berlin, Munich, Leipzig, Göttingen, and Heidel- berg; the Academy of Sciences of Vienna is also affiliated to this group of academies. The situation no doubt presents some difficulties, but it is to be hoped that either by the formation of a Research Council for Germany on which the academies would have representation, or by some other means, a satisfactory solution may be found whereby German men of science may co-operate in the work of the Council and of the Unions.

At the meeting of the Astronomical Union, which was recently held at Leyden, German astronomers accepted an invitation to be present, and their cooperation in the discussions was most welcome. Similarly, German and Austrian chemists were invited to and attended the recent congress of the International Union of Pure and Applied Chemistry which was held at the Hague. On the other hand, a similar invitation which was extended to German geographers to attend the International Geographical Congress, which met at Cambridge in July, was declined by them on the ground that it was organised by the International Union of Geography, one of the Unions related to the International Research Council. Their objection to the Council was based on the ground that it was not wholly a scientific association, but was to some extent a political one, since a government may be the body holding membership. But this only occurs in a few cases where there is not at present a national academy to represent the country. As was stated by the general secretary in his report to the general assembly at the recent meeting of the Council at Brussels, out of the thirty-five countries which have joined the International Research Council, fourteen are represented by their scientific academies, six by national research councils composed of representatives of the national academies, one by a scientific society, and seven others by a scientific department connected with its government. In seven cases only out of the thirty-five is the government the adhering body.

The first twelve-year period of the convention under which the Council and the Unions have been working since 1919 is now drawing to its close, and the Council as well as each of the Unions have to consider the renewal of the convention before its expiration on Dec. 31, 1931. The experience of the past nine years has shown that some modification of the statutes, which were adopted in 1919, may be desirable; the Research Council and the Unions are, therefore, occupying themselves with the revision of them where necessary, in order that any changes that may be advisable may be adopted before the present convention expires.

No. 3072, Vou. 122] 
This should provide a very favourable opportunity for clearing up any misunderstandings that may exist, and for an extension of international cooperation on lines that are acceptable generally. It seems unlikely that the right of governments to adhere to the Council and the Unions can be the sole obstacle to Germany's acceptance. The International Geodetic Association and the Seismological Association of former days were both supported by grants furnished by the governments of the States which were members of the associations ; and so in this respect there has been little change. There may be other matters which are not acceptable, but it does not appear that up to the present any definite and authoritative statement of them has been made public.

As Sir Austen Chamberlain said at the dinner given by the British Government to the delegates to the International Geographical Congress at Cambridge, German statesmen had been welcomed to the Society of Nations as colleagues and as friends; they had contributed fully to the discussions, and he hoped that, before long, German men of science would accept the welcome which awaited them. If a solution of the present difficulties can be found, and they are enabled thereby to accept the invitation to join the Research Council, they will be able to take part in the discussions on the existing statutes and to assist in drafting such modifications in them as will make for the greater efficiency of the organisation as a whole.

\section{Harrison of Ightham.}

Harrison of Ightham: a Book about Benjamin Harrison, of Ightham, Kent, made up principally of Extracts from his Notebooks and Correspondence. Prepared for publication by Sir Edward R. Harrison. Pp. xvi $+395+12$ plates. (London : Oxford University Press, 1928.) 15s. net.

TN writing to Benjamin Harrison, grocer, in the 1 village of Ightham, Kent, in 1906, Sir E. Ray Lankester ended his letter thus: "Good health and happiness to you-courageous and indomitable discoverer of pre-Palæolithic man." Never were words of cheer more timely or better deserved. When this letter reached Harrison he was approaching his seventieth year; he had retired from the counter behind which he had stood for fifty-five years-or to state the matter more truthfully, the counter had retired from him, for the business in which his ancestors had prospered for many generations had become in his hands a rich museum but a poor shop. His only certain source of income then was his Civil List pension of $£ 26$ a year granted in 1899, with, in addition, the annuity of $£ 25$ given to him in the same year by the Royal Society. In 1918, being then in his eightieth year, his Civil List pension was doubled, and this he continued to enjoy until his death in 1921.

Harrison's activities cover a period in which our conception of human history underwent a revolutionary change. His career began in 1851 , while as a schoolboy of thirteen he listened to his eldest brother Tom and his schoolmaster-Stephen Constable-discuss the geology of the Weald, until 1921-a period of seventy years. During this long period, scarcely a morning, an evening, or a Sunday passed without finding him searching his native district for evidence of its prehistory. His pursuits brought him into close contact with the leading geologists, archæologists, and naturalists of the time-Rupert Jones, Grant Allen, Lord Avebury, Sir John Evans, F. C. J. Spurrell, Worthington Smyth, Ray Lankester, Charles Dawson, Lewis Abbott, A. S. Kennard, W. J. Sollas, Smith Woodward, Reid Moir, Russel Wallace, and, above all, Sir Joseph Prestwich, who became his adviser, mentor, and protagonist. It was therefore important that the story of Benjamin Harrison's life should be well and fully told; this has now been done most ably by his son, Sir Edward R. Harrison.

It is quite true that a modern Samuel Smiles could have thrown the glamour of romance over the details of Benjamin Harrison's life, but it is not romance which the historian of science needs, but the sober statement of pertinent facts set out in an orderly and natural manner, and it is this which Sir Edward Harrison has done in the biography of his father. Nowhere does the biographer obtrude himself on the reader; he permits wellchosen extracts from his father's diaries and correspondence to tell the story of a man who was at once one of the most peculiar, yet one of the most outstanding of all the amateurs in science ever bred in England. No claims are made, no defence is set up, no situation is shunned; yet long before the last page is reached it becomes patent to the reader that the biographer is whole-heartedly in sympathy with all his father's labours and aims, and has measured with accuracy their bearing on the trend of scientific discovery. From the pages of this biography emerges the picture of a man, lacking confidence in himself and ever struggling to serve two mistresses-business with her promise of ease, and science with her threat of poverty. Science won every time.

With all the facts now before us, we see that the

No. 3072, Vor. 122] 